\title{
TFRC and ACTB as the best reference genes to quantify Urokinase Plasminogen Activator in breast cancer
}

\author{
Keivan Majidzadeh-A*, Rezvan Esmaeili and Nasrin Abdoli
}

\begin{abstract}
Background: Biomedical researchers have long looked for ways to diagnose and treat cancer patients at the early stages through biomarkers. Although conventional techniques are routinely applied in the detection of biomarkers, attitudes towards using Real-Time PCR techniques in detection of many biomarkers are increasing. Normalization of quantitative Real-Time PCR is necessary to validate non-biological alteration occurring during the steps of RNA quantification. Selection of variably expressed housekeeping genes (HKs) will affect the validity of the data. The aim of the present study was to identify uniformly expressed housekeeping genes in order to use in the breast cancer gene expression studies. Urokinase Plasminogen Activator was used as a gene of interest.

Findings: The expression of six HKs (TFRC, GUSB, GAPDH, ACTB, HPRT1 and RPLPO) was investigated using geNorm and NormFinder softwares in forty breast tumor, four normal and eight adjacent tissues. RPLPO and GAPDH revealed maximum $M$ value, while TFRC demonstrated lowest $M$ value.

Conclusions: In the present study the most and the least stable genes were TFRC and RPLPO respectively. TFRC and ACTB were verified as the best combination of two genes for breast cancer quantification. The result of this study shows that in each gene expression analysis HKs selection should be done based on experiment conditions.
\end{abstract}

\section{Introduction}

Worldwide, breast cancer is the most frequent cancer among women. It affects more than one million women globally, accounting for more than 400,000 deaths annually [1]. In Iran as an Asian country, among women over 30 , the incidence and prevalence rate of breast cancer is 22 and 120 per 100,000 , respectively [2].

For a long time, biomedical scientists have been interested in finding ways to diagnose and to treat cancer patients at early stages. Research aimed at developing robust biomarkers and reliable assays, has made progress in the detection, diagnosis, and treatment of breast cancer. Only a limited number of biomarkers for breast cancer are currently available which assist in making breast cancer management decisions. Oncotype DX; a diagnostic panel commercially available; is indicated for specified breast cancer patients that predicts the risk of

\footnotetext{
* Correspondence: kmajidzadeh@razi.tums.ac.ir Iranian Center for Breast Cancer (ICBC); Academic Center for Education, Culture and Research (ACECR) No 45, Nazari St, Aboureihan St, Enghelab Ave, Tehran, Iran
}

(c) 2011 Majidzadeh-A et al; licensee BioMed Central Ltd. This is an open access article distributed under the terms of the Creative Commons Attribution License (http://creativecommons.org/licenses/by/2.0), which permits unrestricted use, distribution, and reproduction in any medium, provided the original work is properly cited. tor (ER), progesterone receptor (PR) and Her2/neu status are routinely measured to decide about hormone and targeted therapy. In addition, recommendations concerning the role of urokinase plasminogen activator (uPA) in detecting the invasive nature of the tumors have been recently added to the clinical guidelines [4].

Current routine assays for quantifying biomarkers, such as immunohistochemistry (IHC) and Enzymelinked immunosorbent assay (ELISA) are approved and valid, and are reproducible between different laboratories [5-8]. However, unquantifiable results and long procedure time are among the drawbacks of these methods which have persuaded researchers to seek alternative modern molecular based techniques such as quantitative Real-Time PCR (Q-RT-PCR) [9,10]. Q-RTPCR is highly cost-effective, very fast, and one of the most sensitive and specific quantification methods for gene expression analysis [11,12].

To be approved as a routine alternative method for conventional techniques; however, a number of 
validations are necessary for Q-RT-PCR including HK validation. Differences occurring during the steps of RNA quantification would be normalized by endogenous controls (ECs). There are large scale gene expression profiling studies in which hundreds of HKs were identified [13-15]. During the years of using Q-RT-PCR, based on this belief that housekeeping genes have uniform expression regardless of biological conditions, they have been applied for quantification. Several studies have revealed significant alterations in the expression of a number of ECs affecting validity of expression analysis [16-20]. Since reliability of ECs affects the accuracy of the normalized data, reference gene selection plays an important role in this matter. HK validations have been performed for a number of genes but, to the best of our knowledge, no report has been found for uPA in breast cancer. The uPA is involved in various biological processes. Along with some other genes, elevated expression of uPA in plasminogen activation system takes part in tumor cell invasion and metastatic process. High level expression of this marker represents an unfavorable prognostic factor for metastasis in breast cancer $[6,21]$. The aim of the present study was to validate reference genes in order to select the most appropriate ECs for uPA quantification in breast cancer tissues.

\section{Methods}

Breast tumor tissues $(n=40)$, normal tissues $(n=4)$ and normal adjacent tissues $(\mathrm{n}=8)$, were taken from Iranian Center for Breast Cancer Biobank (ICBC-BB). According to the protocols followed by ICBC-BB, immediately after excisional biopsy or surgery, sample tissues were snap-frozen in liquid nitrogen and stored at $-70^{\circ} \mathrm{C}$. $\mathrm{ICBC}-\mathrm{BB}$ is obliged to ethical guidelines and recommendations for biobanks on the storage and use of human biological samples. Clinical and histopathological features of patients are summarized in table 1 .

Tissues $(8-20 \mathrm{mg})$ were excised on dry ice and homogenized in $1 \mathrm{ml}$ of RnxPlus (Cinnagen, Iran) to extract RNA according to manufacturer directions. Extracted RNAs were quantified by spectrophotometer (Hitachi, U-0080D, Japan) and the Absorbance ratio at 260/280 and 260/230 were measured to control the purity of the RNA. The integrity of RNA was confirmed by checking ribosomal RNA with electrophoresis on a $1 \%$ agarose gel. Then, $3.6 \mu \mathrm{g}$ of RNA was treated with 18 unit of RNase-free DNase (Fermentas AB, Vilnius, Lithuania), 20 units of RNase inhibitor (Fermentas AB, Vilnius, Lithuania) and $2.4 \mu \mathrm{l}$ of $25 \mathrm{mM} \mathrm{MgCl}$. The total volume of reaction was $30 \mu \mathrm{l}$. The reaction was incubated in $37^{\circ} \mathrm{C}$ for $15 \mathrm{~min}$ and then $90^{\circ} \mathrm{C}$ for $5 \mathrm{~min}$ to inactivate the DNase. $1 \mu \mathrm{g}$ of total RNA was transcribed to cDNA using Precision ${ }^{\mathrm{TM}}$ reverse transcription kit (PrimerDesign Ltd, UK).
Six common housekeeping genes in breast cancer; TFRC, GUSB, GAPDH, ACTB, HPRT1 and RPLP0; were selected and their stability were examined in order to normalize expression of uPA. All primers and probes were designed using Gene Runner v.3.05 and confirmed with primer express 3.0 (Table 2). Amplification efficiency for each primer was approximated using 10 fold cDNA serial dilutions and calculated using 7500 software system ver. 2.0. The serial dilutions were performed using pooled cDNA from 15 tumor cDNAs with equal proportion. CDNA synthesis was done as mentioned above.

\section{Quantitative Real-Time PCR}

Q-RT-PCR was carried out in triplicate format within the same 96-well plate for each sample using precision $^{\mathrm{TM}} 2 \times \mathrm{qPCR}$ Mastermix (PrimerDesign Ltd, UK) in $20 \mu \mathrm{l}$ reactions. Primer and probe concentrations were $0.5 \mu \mathrm{M}$ and $0.3 \mu \mathrm{M}$, respectively. Fluorescent detection was performed using Applied Biosystems 7500 System. Data were analyzed using SDS software, vers.2.0 (Applied Biosystems).

\section{Data analysis and endogenous control stability}

Raw data of Q-RT-PCR was analyzed using SDS software, vers.2.0 (Applied Biosystems). Samples with standard deviation greater than 0.5 from the mean threshold cycle $(\mathrm{CT})$ of the replicates were excluded. In order to find the most stable housekeeping gene, the data were transformed to linear scale values with Excel. Analyses were done by pairwise comparison approach applying geNorm software[19] as well as combined estimation of the intra and inter group validation using NormFinder software[22]. UPA expression measurement was performed using $\triangle \triangle C T$ method with RPLPO or combination of ACTB and TFRC as endogenous control. Comparison between the mean of each group was done using paired sample t-test (SPSS v.13) with 95\% confidence interval.

\section{Results}

Threshold cycle (CT) values of endogenous controls and uPA are shown in table 3.

The range of threshold cycles (CT Range) was between 8.61 and 22.68 among endogenous candidate genes with a mean value ranging from 25.1 ( \pm 0.5 s.e.m) for ACTB to 32.61 ( \pm 0.43 s.e.m) for GUSB. The maximum and minimum expression ranges were 22.68 cycles for GUSB and 8.61 cycles for ACTB respectively (Table3).

Data were analyzed using geNorm and NormFinder software programs. GeNorm calculates pairwise variation to find the most stable expressed ECs, and thereby computing the average expression stability value $(\mathrm{M})$ 
Table 1 Clinical and histological data of malignant and normal adjacent breast tissues.

\begin{tabular}{|c|c|c|c|c|c|c|c|c|c|c|}
\hline Tissue type & Age & Size $(\mathrm{mm})$ & Tumor stage & grade & Histological type & Menoposal status & ER & PR & Her2/neu & P53 \\
\hline Adjacent & 50 & & & & & & & & & \\
\hline Adjacent & 38 & & & & & & - & - & - & + \\
\hline Malignant & 38 & 18 & $\| \mathrm{A}$ & III & IDC & pre & + & + & - & \\
\hline Malignant & 38 & 20 & & III & IDC & pre & $3+$ & $3+$ & $2+$ & \\
\hline Malignant & 58 & 35 & $\| \mathrm{A}$ & $\|$ & IDC & post & - & - & - & + \\
\hline Malignant & 80 & 10 & & I & IDC & post & + & + & - & \\
\hline Malignant & 54 & 30 & $\| \mathrm{B}$ & $\|$ & IDC & post & & & & \\
\hline Adjacent & & & & & & & + & + & $3+$ & + \\
\hline Malignant & 40 & 25 & $\| \mathrm{B}$ & $\|$ & IDC & pre & + & + & - & + \\
\hline Malignant & 35 & 20 & & III & IDC & post & & & & \\
\hline \multicolumn{11}{|l|}{ Adjacent } \\
\hline Malignant & & & & & & & + & + & - & + \\
\hline Malignant & 52 & 21 & $\| \mathrm{A}$ & $\|$ & IDC & post & + & + & - & + \\
\hline Malignant & & & III & & IDC & & + & - & - & + \\
\hline Malignant & 82 & 50 & $\| \mathrm{B}$ & III & IDC & post & & & & \\
\hline Adjacent & 43 & & & & & & + & + & - & - \\
\hline Malignant & 50 & 50 & $\| \mathrm{A}$ & $\|$ & IDC & pre & $3+$ & $3+$ & - & \\
\hline Malignant & 44 & 20 & $\| I I A$ & III & IDC & pre & + & + & - & \\
\hline Malignant & 51 & 20 & $\| A$ & $\|$ & IDC & post & & & & \\
\hline Malignant & & & & & & & + & + & - & - \\
\hline Malignant & 37 & 60 & 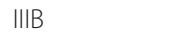 & $\|$ & IDC & post & & & & \\
\hline Malignant & 45 & & & & IDC & pre & + & + & - & \\
\hline Malignant & 40 & 15 & IB & $\|$ & IDC & pre & - & - & - & + \\
\hline Malignant & 42 & 20 & IV & III & IDC & pre & + & + & - & + \\
\hline Malignant & 52 & 21 & $\| \mathrm{A}$ & $\|$ & IDC & post & + & + & - & - \\
\hline Malignant & 50 & 8 & $\| \mathrm{A}$ & $\|$ & IDC & post & + & + & - & \\
\hline Malignant & 54 & 30 & $\| \mathrm{A}$ & $\|$ & IDC & post & - & - & - & - \\
\hline Malignant & 45 & & IV & & IDC & pre & & & & \\
\hline Adjacent & 45 & & & & & & & & & \\
\hline Adjacent & 40 & & & & & & & & & \\
\hline Adjacent & 52 & & & & & & & & & \\
\hline Adjacent & 42 & & & & & & - & - & - & - \\
\hline Malignant & 53 & & & & $\mathrm{IDC}+\mathrm{DCIS}$ & pre & + & + & $3+$ & - \\
\hline Malignant & 34 & 10 & $\| \mathrm{B}$ & $\|$ & $\mathrm{IDC}+\mathrm{DCIS}$ & pre & - & - & - & + \\
\hline Malignant & 56 & 38 & $\| \mathrm{B}$ & $\|$ & IDC & post & + & + & - & \\
\hline Malignant & 71 & 20 & IV & $\|$ & IDC & post & - & - & - & - \\
\hline Malignant & 34 & 30 & $\| \mathrm{A}$ & $\|$ & IDC & pre & + & + & $3+$ & \\
\hline Malignant & 37 & & & $\|$ & IDC & pre & - & - & - & \\
\hline Malignant & 48 & 30 & $\| \mathrm{B}$ & & ILC & pre & + & + & - & + \\
\hline Malignant & 43 & 18 & I & & & pre & - & + & - & \\
\hline Malignant & 45 & 20 & $\|$ & $\|$ & $\mathrm{ILC}$ & pre & - & - & $3+$ & + \\
\hline Malignant & 39 & 100 & $\| \mathrm{A}$ & $\|$ & IDC & pre & & & & \\
\hline Malignant & 34 & 60 & & III & IDC & pre & & & & \\
\hline \multicolumn{11}{|l|}{ Malignant } \\
\hline Normal & 25 & & & & & & & & & \\
\hline Normal & 38 & & & & & & & & & \\
\hline Normal & 32 & & & & & & & & & \\
\hline Normal & & & & & & & + & + & - & - \\
\hline Malignant & 50 & 15 & IB & 1 & IDC & pre & - & - & $3+$ & + \\
\hline Malignant & 32 & 10 & IV & $\|$ & IDC & pre & + & - & - & \\
\hline Malignant & 60 & 30 & IV & $\|$ & IDC & post & + & + & - & - \\
\hline Malignant & 41 & 50 & IV & I & IDC & pre & & & & \\
\hline
\end{tabular}

Stage grouping are based on American Joint Committee on Cancer (AJCC). Estrogen receptor(ER), progesterone receptor (PR), Her2/neu and P53 status are based on IHC results. Invasive ductal carcinoma (IDC), invasive lobular carcinoma (ILC) 
Table 2 Primer probe sets.

\begin{tabular}{|c|c|c|c|c|}
\hline Target & Accession No. & Sequence & Melting TM & efficiency \\
\hline \multirow[t]{3}{*}{ GAPDH } & NM_001002 & F GAAGGTGAAGGTCGGAGTC & 61.3 & 94 \\
\hline & & R GGGTGGAATCATATTGGAACA & 63.2 & \\
\hline & & P ATTTGGTCGTATTGGGCGCCTGGT & 74.9 & \\
\hline \multirow[t]{3}{*}{ TFRC } & NM_003234 & F ACCGGCACCATCAAGCT & 64.5 & 94 \\
\hline & & R TGATCACGCCAGACTITGC & 65.2 & \\
\hline & & P TGAAAATTCATATGTCCCTCGTGAGGCT & 72.1 & \\
\hline \multirow[t]{3}{*}{ RPLPO } & NM_001002 & F CGGACGAGGATATGGGATTTG & 67.2 & 89 \\
\hline & & R AGAAGTAAGCCTITATTTCCTTGTTा & 64.7 & \\
\hline & & P TCACCAAAAAGCAACCAACTTAGCCAGT & 72 & \\
\hline \multirow[t]{3}{*}{ GUSB } & NM_000181 & F GCGTTCCTTTTGCGAGGAGA & 68.6 & 74 \\
\hline & & R GGTGGTATCAGTCTTGCTCAA & 64.7 & \\
\hline & & P ACCAGGTATCCCCACTCAGTAGCCAAG & 72 & \\
\hline \multirow[t]{3}{*}{ HPRT1 } & NM_000194 & F TGGACTAATTATGGACAGGACTGAA & 64.4 & 103 \\
\hline & & R GTAATCCAGCAGGTCAGCAA & 62.8 & \\
\hline & & P CTTGCTCGAGATGTGATGAAGGAGATGG & 73.7 & \\
\hline \multirow[t]{3}{*}{ UPA } & NM_002658 & F AGGGCAGCACTGTGAAATAGATAAGT & 65.7 & 97 \\
\hline & & R CATGGTACGTTTGCTGAAGGA & 64.8 & \\
\hline & & P TTACCGAGGAAAGGCCAGCACTGACA & 75.3 & \\
\hline \multirow[t]{3}{*}{ ACTB } & NM_001101 & F CAGCAGATGTGGATCAGCAAG & 65.9 & 95 \\
\hline & & R GCATTTGCGGTGGACGAT & 67.1 & \\
\hline & & P AGGAGTATGACGAGTCCGGCCCC & 73.8 & \\
\hline
\end{tabular}

Probes were labeled with 5' FAM and 3' TAMRA.

and plotting it for each gene. In this study, RPLP0 and GAPDH revealed maximum $M$ while TFRC demonstrated lowest $M$ value (Figure 1). The most stable expressed gene was TFRC. The GeNorm software also calculates normalization factor $(\mathrm{V})$; the point at which addition of extra endogenous control is unnecessary; to find the optimal number of required ECs. According to GeNorm software manual, recommended V-value cutoff was 0.15 but it was also mentioned that proposed value must not be taken as a too strict cut-off. In this study the V-values of using 3 and 4 ECs were calculated as 0.5 and 0.4 , respectively (Figure 2).

NormFinder software; an algorithm for identifying the optimal normalization gene among a set of candidates; was used to rank the set of candidate normalization genes according to their expression stability in a given

Table 3 threshold cycle (CT) values of endogenous controls and uPA.

\begin{tabular}{ccccc}
\hline Gene & CT Range & CT Min & CT Max & Mean \pm s.e.m \\
\hline RPLP0 & 22.68 & 19.52 & 42.2 & $29.69 \pm 0.81$ \\
GUSB & 8.61 & 27.59 & 36.2 & $31.99 \pm 0.33$ \\
TFRC & 15.64 & 25.27 & 40.92 & $31.7 \pm 0.5$ \\
HPRT1 & 14.25 & 26.42 & 40.67 & $32.61 \pm 0.43$ \\
ACTB & 14.05 & 16.93 & 30.98 & $25.1 \pm 0.5$ \\
GAPDH & 19.2 & 22.69 & 41.89 & $29.3 \pm 0.5$ \\
UPA & 10.65 & 28.13 & 38.78 & $31 \pm 0.38$ \\
\hline
\end{tabular}

sample set. In this study, NormFinder determined TFRC as the most stable EC Followed by GUSB and ACTB genes (Table 4).

Statistical comparison of "uPA expression results normalized with RPLP0" in one group and "the combination of TFRC and ACTB" in another group showed significant difference in uPA expression amounts (pvalue $<0.05)$.

\section{Discussion}

During recent years traditional attitudes towards therapeutic care has been replaced with individualized medicine especially in the cancer field. It is recommended to assess approved markers in order to select the best therapeutic models instead of blind administration of similar regimens for all patients.

Among current systems, gene expression profiling plays a major role in tailoring treatment to the individual strategy. Despite the accuracy of routinely used approved methods for detection of biomarkers such as IHC for measurement of Her2 and ER biomarkers and ELISA for uPA, there are still disadvantages. For instance, ELISA requires a substantial amount of tissue and small tissues of early stage cancer would be difficult to be analyzed [4]. Several studies using various types of design have been conducted to determine whether novel molecular techniques like QRT-PCR may be added to routine approved methods for detection and quantification of biomarkers [23-31]. 


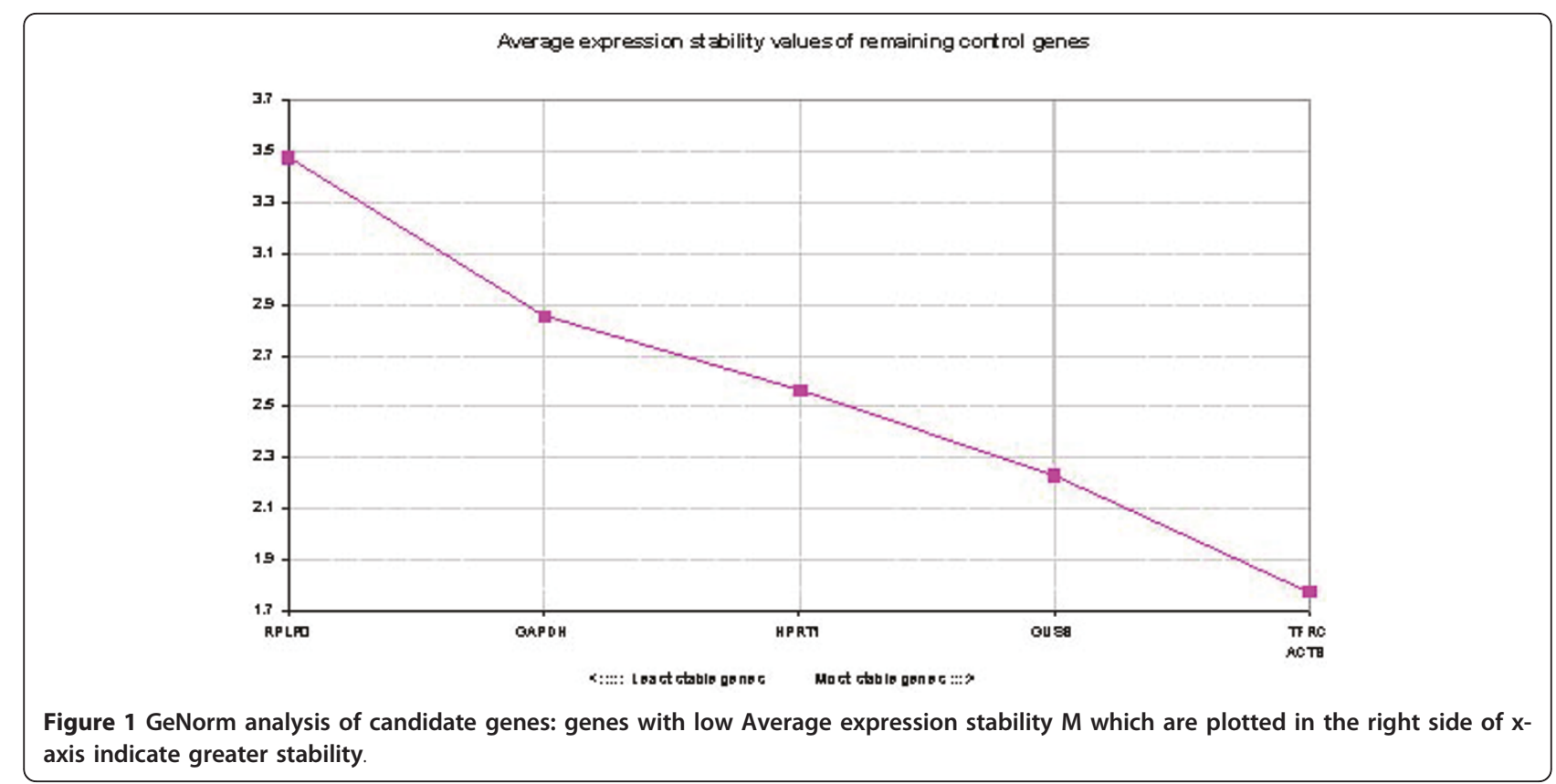

To our knowledge this is the first study on determining reference gene in breast cancer for quantification of uPA. We found that TFRC and ACTB is the best combination of two genes with the greatest expression stability. GeNorm and NormFinder without sub grouping had a similar performance in detecting the most and the least stable genes. TFRC and RPLP0 were the most and the least satiable genes. GAPDH and ACTB were among the least and the most stable genes which a in concordance with other breast cancer studies [17,32-35]. Both softwares recognized the same order of stability for all of the genes (Table4). Other Studies suggest different genes. Mc Neill et al in a study for ER quantification, suggested MRPL19 and PPIA as the most stable and RPLP0 as the least stable genes, while in the study by Lyng et al TBP, RPLP0 and PUM1 were recommend for normalization [36]. Moreover, $18 \mathrm{~S}$ rRNA and HPRT1 have been suggested for breast cancer normalization in quantification of Her2/neu $[18,34]$.

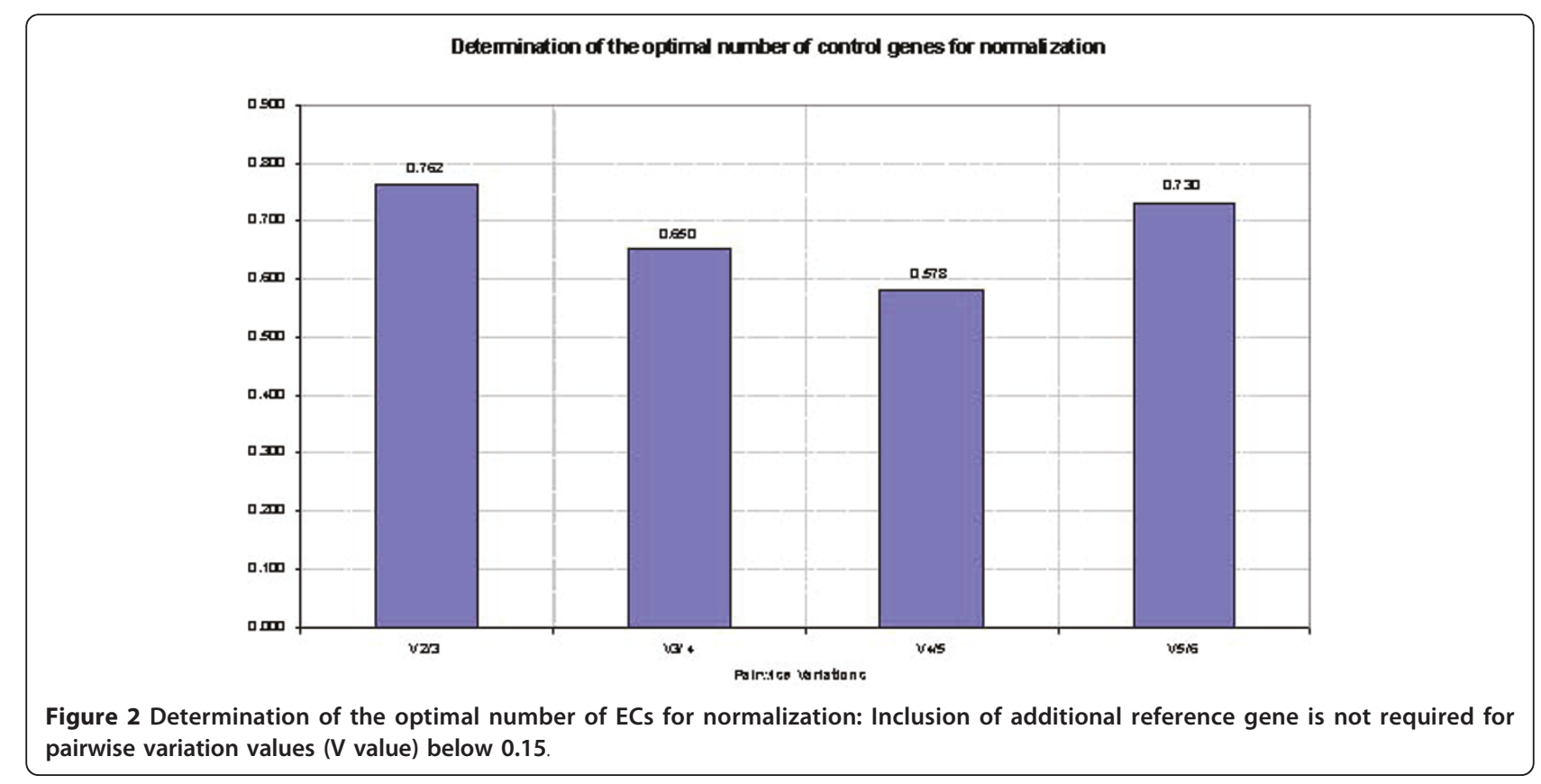


Table 4 Stability values of reference genes using geNorm and NormFinder programs

\begin{tabular}{lllll}
\hline \multicolumn{3}{l}{ geNorm } & \multicolumn{3}{c}{ NormFinder } \\
\hline Rank & Gene name & Stability (M value) & Gene name & Stability \\
\hline 1 & TFRC & 2.846 & TFRC & 0.796 \\
2 & GUSB & 2.902 & GUSB & 1.007 \\
3 & ACTB & 2.984 & ACTB & 1.130 \\
4 & HPRT1 & 3.298 & HPRT1 & 1.799 \\
5 & GAPDH & 3.538 & GAPDH & 1.984 \\
6 & RPLPO & 4.737 & RPLPO & 2.966 \\
\hline
\end{tabular}

Genes with lower number are more stable.

Housekeeping selection is a critical step in Q-RT-PCR analysis. The idea that housekeeping genes (ECs) pose constant expression in different cells may influence their selection in various studies. In the study by Mc Neill et al the data of housekeeping gene selection in colorectal and ovarian cancer was used to decide about selection of an EC for breast cancer [17]. It should be noted that instability of one housekeeping gene in specific cancer does not mean instability in other cancers. The important key is that housekeeping gene expression patterns are influenced by cancer mechanism and EC selections should be made for each cancer separately $[37,38]$. Housekeeping generalization may result in inappropriate set of ECs because some genes may be included or excluded erroneously based on other cancer evidences.

It is also noteworthy that various experiment conditions in the studies may change the expression of the housekeeping genes. As a result, dissimilar genes may be found as the best reference for normalization in different studies with different conditions.

\section{Conclusions}

To conclude, it appears that identifying a universal housekeeping for gene expression analysis is far from reality. Thus, stability of controls should be checked based on the tissue type and experiment design. On the basis of our findings, we suggest that TFRC is the most stable EC, ACTB and TFRC is the best combination of two reference genes to quantify uPA, and that using RPLP0 and GAPDH are not recommendable for breast cancer. The authors also suggest testing with large sample size and more candidate reference gene to find more stable ECs.

\section{Acknowledgements}

The authors would like to acknowledge the Academic Center for Education, Culture and Research (ACECR) for financial support.

\section{Authors' contributions}

KM conceived and designed the project and critically reviewed data analysis and manuscript. RE designed the experiment, was responsible for experiments set up, data analysis and writing the manuscript. NA was responsible for collecting samples and performing the experiments. All authors read and approved the final manuscript.

\section{Competing interests}

The authors declare that they have no competing interests.

Received: 20 October 2010 Accepted: 25 June 2011

Published: 25 June 2011

\section{References}

1. Steven SC, Donatus U, b E: Breast cancer as a global health concern. Cancer Epidemiology 2009, 33:315-318.

2. Mousavi SM, Montazeri A, Mohagheghi MA, Jarrahi AM, Harirchi I, Najafi M, Ebrahimi M: Breast cancer in Iran: an epidemiological review. Breast J 2007, 13:383-391.

3. Paik S, Shak S, Tang G, Kim C, Baker J, Cronin M, Baehner FL, Walker MG, Watson D, Park T, et al: A Multigene Assay to Predict Recurrence of Tamoxifen-Treated, Node-Negative Breast Cancer. N Engl J Med 2004, 351:2817-2826.

4. Harris L, Fritsche H, Mennel R, Norton L, Ravdin P, Taube S, Somerfield MR, Hayes DF, Bast RC Jr: American Society of Clinical Oncology 2007 Update of Recommendations for the Use of Tumor Markers in Breast Cancer. J Clin Oncol 2007, 25:5287-5292.

5. Look M, van Putten W, Duffy M, Harbeck N, Christensen IJ, Thomssen C, Kates R, Spyratos F, Fernö M: Pooled Analysis of Prognostic Impact of Urokinase-Type Plasminogen Activator and Its Inhibitor PAI-1 in 8377 Breast Cancer Patients. Thromb Haemost 2003, 90:538-548.

6. Foekens JA, Schmitt M, van Putten WL, Peters HA, Bontenbal M, Jänicke $F$ Klijn JGM: Prognostic Value of Urokinase-type Plasminogen Activator in 671 Primary Breast Cancer Patients. Cancer Research 1992, 52:6101-6105.

7. Foekens JA, Peters HA, Look MP, Portengen H, Schmitt M, Kramer MD, Brünner N, Jänicke F, Gelder MEM-V, Henzen-Logmans SC, et al: The Urokinase System of Plasminogen Activation and Prognosis in 2780 Breast Cancer Patients. Cancer Research 2000, 60:636-643.

8. Benraad TJ, Geurts-Moespot J, Grøndahl-Hansen J, Schmitt M, Heuvel JJ, de Witte JH, Foekens J, Leake R, Brünner N, Sweep C: Immunoassays (ELISA) of Urokinase-type Masminogen Activator (u.PA): Report of an EORTCIBIOMED-1 Workshop. Eur J Cancer 1996, 32A:1371-1381.

9. Schnitt SJ: Breast Cancer in the 21st Century: Neu Opportunities and Neu Challenges. Mod Pathol 2001, 14:213-218.

10. Yaziji H, Gown AM: Testing for HER-2/neu in Breast Cancer: Is Fluorescence In Situ Hybridization Superior in Predicting Outcome? Adv Anat Pathol 2002, 9:338-344.

11. Valasek MA, Repa JJ: The power of real-time PCR. Adv Physiol Educ 2005, 29:151-159.

12. Walker NJ: Tech.Sight. A technique whose time has come. Science 2002, 296:557-559.

13. de la Grange P, Dutertre M, Martin N, Auboeuf D: FAST DB: a website resource for the study of the expression regulation of human gene products. Nucleic Acids Res 2005, 33:4276-4284.

14. Eisenberg $E$, Levanon $E Y$ : Human housekeeping genes are compact. Trends Genet 2003, 19:362-365.

15. Hsiao LL, Dangond F, Yoshida T, Hong R, Jensen RV, Misra J, Dillon W, Lee KF, Clark KE, Haverty $P$, et al: A compendium of gene expression in normal human tissues. Physiol Genomics 2001, 7:97-104.

16. Révillion F, Pawlowski V, Hornez L, Peyrat JP: Glyceraldehyde-3-phosphate dehydrogenase gene expression in human breast cancer. Eur J Cancer 2000, 36:1038-1042.

17. McNeill RE, Miller N, Kerin MJ: Evaluation and validation of candidate endogenous control genes for real-time quantitative PCR studies of breast cancer. BMC Mol Biol 2007, 27:107-119.

18. de Kok JB, Roelofs RW, Giesendorf BA, Pennings JL, Waas ET, Feuth T, Swinkels DW, Span PN: Normalization of gene expression measurements in tumor tissues: comparison of 13 endogenous control genes. Lab Invest 2004, 85:154-159.

19. Vandesompele J, De Preter K, Pattyn F, Poppe B, Van Roy N, De Paepe A, Speleman F: Accurate normalization of real-time quantitative RT-PCR data by geometric averaging of multiple internal control genes. Genome Biol 2002, 3:RESEARCH0034 
20. Li YL, Ye F, Hu Y, Lu WG, Xie X: Identification of suitable reference genes for gene expression studies of human serous ovarian cancer by realtime polymerase chain reaction. Anal Biochem 2009, 394:110-116.

21. Killeen S, Hennessey A, El Hassan Y, Waldron B: The urokinase plasminogen activator system in cancer: a putative therapeutic target? Drug News Perspect 2008, 21:107-116.

22. Andersen $C$, Jensen J, Orntoft T: Normalization of real-time quantitative reverse transcription-PCR data: a model-based variance estimation approach to identify genes suited for normalization, applied to bladder and colon cancer data sets. Cancer Res 2004, 64:5245-5250.

23. Castelló R, Estellés A, Vázquez C, Falcó C, España F, Almenar SM, Fuster C, Aznar J: Quantitative Real-Time Reverse Transcription-PCR Assay for Urokinase Plasminogen Activator, Plasminogen Activator Inhibitor Type 1, and Tissue Metalloproteinase Inhibitor Type 1 Gene Expressions in Primary Breast Cancer. Clin Chem 2002, 48:1288-1295.

24. Biermann J, Holzscheiter L, Kotzsch M, Luther T, Kiechle-Bahat M, Sweep F, Span P, Schmitt M, Magdolen V: Quantitative RT-PCR assays for the determination of urokinase-type plasminogen activator and plasminogen activator inhibitor type $1 \mathrm{mRNA}$ in primary tumor tissue of breast cancer patients: comparison to antigen quantification by ELISA. Int J Mol Med 2008, 21:251-259.

25. Pierga JY, Bonneton C, Magdelénat H, Vincent-Salomon A, Nos C, Boudou E, Pouillart P, Thiery JP, Cremoux Pd: Real-time quantitative PCR determination of urokinase-type plasminogen activator receptor (UPAR) expression of isolated micrometastatic cells from bone marrow of breast cancer patients. International Journal of Cancer 2005, 114:291-298.

26. Konigshoff M, Wilhelm J, Bohle RM, Pingoud A, Hahn M: HER-2/neu Gene Copy Number Quantified by Real-Time PCR: Comparison of Gene Amplification, Heterozygosity, and Immunohistochemical Status in Breast Cancer Tissue. Clin Chem 2003, 49:219-229.

27. Schlemmer BO, Sorensen BS, Overgaard J, Olsen KE, Gjerdrum LM, Nexo E: Quantitative PCR - new diagnostic tool for quantifying specific mRNA and DNA molecules: HER2/neu DNA quantification with LightCycler realtime PCR in comparison with immunohistochemistry and fluorescence in situ hybridization. Scandinavian Journal of Clinical \& Laboratory Investigation 2004, 64:511-522.

28. Capizzi E, Gruppioni E, Grigioni A, Gabusi E, Grassigli A, Grigioni W, Fiorentino M: Real time RT-PCR approach for the evaluation of ERBB2 overexpression in breast cancer archival samples: a comparative study with FISH, SISH, and immunohistochemistry. Diagn Mol Pathol 2008, 17:220-226.

29. Nistor A, Watson P, Pettigrew N, Tabiti K, Dawson A, Myal Y: Real-time PCR complements immunohistochemistry in the determination of HER-2/neu status in breast cancer. BMC Clinical Pathology 2006, 6:2.

30. Becette $\mathrm{V}$, Vignaud $\mathrm{S}$, Régnier $\mathrm{C}$, Labroquére $\mathrm{M}$, Fourme $\mathrm{E}$, Menet $\mathrm{E}$, Bièche I, Spyratos F: Gene transcript assay by real-time RT-PCR in epithelial breast cancer cells selected by laser microdissection. $t$ J Biol Markers 2004, 19:100-108.

31. de Cremoux P, Tran-Perennou C, Brockdorff B, Boudou E, Brunner N, Magdelenat H, Lykkesfeldt A: Validation of real-time RT-PCR for analysis of human breast cancer cell lines resistant or sensitive to treatment with antiestrogens. Endocr Relat Cancer 2003, 10:409-418.

32. Larionov A, Dixon J, Krause A, Evans D, Miller W: Validation of reference genes for relative real time PCR to study hormone-dependent gene expression in breast cancer biopsies. Breast Cancer Res Treat 2005, 94.

33. Drury S, Anderson H, Dowsett M: Selection of REFERENCE Genes for Normalization of qRT-PCR Data Derived From FFPE Breast Tumors. Diagnostic Molecular Pathology 2009, 18:103-107.

34. Morse DL, Carroll D, Weberg L, Borgstrom MC, Ranger-Moore J, Gillies RJ: Determining suitable internal standards for mRNA quantification of increasing cancer progression in human breast cells by real-time reverse transcriptase polymerase chain reaction. Analytical Biochemistry 2005, 342:69-77.

35. Gur-Dedeoglu B, Konu O, Bozkurt B, Ergul G, Seckin S, Yulug I: Identification of endogenous reference genes for QRT-PCR analysis in normal matched breast tumor tissues. Oncol Res 2009, 17:353-365.

36. Lyng M, Laenkholm A, Pallisgaard N, Ditzel H: Identification of genes for normalization of real-time RT-PCR data in breast carcinomas. BMC Cancer :20 2008, Jan 22:20.

37. Waxman $\mathrm{S}$, Wurmbach E: De-regulation of common housekeeping genes in hepatocellular carcinoma. BMC Genomics 2007, 18:243.
38. Khimani A, Mhashilkar A, Mikulskis A, O'Malley M, Liao J, Golenko E, Mayer P, Chada S, Killian J, Lott S: Housekeeping genes in cancer: normalization of array data. Biotechniques 2005, 38:739-745.

doi:10.1186/1756-0500-4-215

Cite this article as: Majidzadeh-A et al:: TFRC and ACTB as the best reference genes to quantify Urokinase Plasminogen Activator in breast cancer. BMC Research Notes 2011 4:215.

\section{Submit your next manuscript to BioMed Central and take full advantage of:}

- Convenient online submission

- Thorough peer review

- No space constraints or color figure charges

- Immediate publication on acceptance

- Inclusion in PubMed, CAS, Scopus and Google Scholar

- Research which is freely available for redistribution

Submit your manuscript at www.biomedcentral.com/submit
Biomed Central 